\title{
From Skills to Stories: Land Rights, Life Histories and the Terms of Engagement
}

\section{Introduction: Ian Keen and the Alligator Rivers Land Claims}

In the 1970s, in the Alligator Rivers region of the Northern Territory, things changed. From being a region of small-scale economic activity that had only recently achieved a modest level of significance even within the Territory, it became a national political hotspot, as the contentious policy discourses of uranium development, Aboriginal land rights and environmental conservation converged and collided over the same area of ground. Saddler (1980) called it 'the battle for the Alligator Rivers'. In 1975 Ian Keen, a doctoral research student working at Milingimbi in northeast Arnhem Land, suddenly found himself in the middle - and an agent - of that transformation.

The Alligator Rivers region had become known as the Uranium Province following the major discoveries there in the years 1969 to 1973. In 1975, before any mining was allowed, the Ranger Uranium Environmental Inquiry (RUEI) was established and began taking evidence on possible future land uses in the region (RUEI 1977: 7-8). In Canberra, legislation was being drafted to introduce Aboriginal land rights into the Northern Territory, and the Australian Institute of Aboriginal Studies agreed to a request from the nascent Northern Land Council in Darwin to provide anthropologists to begin preparing land claims 
(Ucko 1976: 7-8). Plainly, the vacant Crown land in the Alligator Rivers region was a priority area for the first round of claims. At the end of his first major period of field research at Milingimbi, the student Keen was contacted by the principal of the institute, Peter Ucko, and directed to go west and carry out that Alligator Rivers research. Of the seven researchers seconded into that first wave of land claim research across the NLC's region of responsibility, Ian was the only one asked to work outside his existing field area.

To prepare the claim, Ian, with the Northern Territory Museum's George Chaloupka, visited Aboriginal camps between Darwin, Oenpelli and Katherine. Then with four Aboriginal men, one of whom is discussed in this chapter, they carried out a brief period of fast and intense fieldwork within the claim area. Keen documented clan groups, their genealogies and principles of attachment to land; Chaloupka mapped sites and clan territories. Ian was familiar with patrilineal clan territories from northeast Arnhem Land, and adopted a similar model from the Berndts' (1970) work on the Kunwinjku of western Arnhem Land. There was only the proposed form of the legislation and the advice of NLC lawyers to guide them in the framing of a land claim. With these constraints, they produced a tentative account of traditional ownership over part of the area available for claim. The Aboriginal Land Rights (Northern Territory) Act was finally passed at the end of 1976, and in effect authorised the Ranger Inquiry to hear this first land claim (RUEI 1977: 6). Keen's and Chaloupka's reports then became a major source of the evidence considered by the inquiry (Keen 1975; Chaloupka 1975; RUEI 1977: 256-8).

In addition, Ian contributed to an argument put successfully by the Northern Land Council that extant clan groups succeeded to ownership of the territories of clans that had died out, and that that succession could take effect immediately on the death of the last previous owner (Peterson, Keen and Sansom 1977; RUEI 1977: 259-60, 265). Together, the claim evidence and the succession argument allowed the inquiry to find that traditional owners as defined by the Act existed over a large part of the claim area (RUEI 1977: 277-83). Ian later wrote that the inquiry's acceptance of a process of immediate succession represented the first significant extension of the category of 'traditional Aboriginal owners' beyond the orthodox anthropological model that had been adopted by the Aboriginal Land Rights Commission and imported into the Land Rights Act (Keen 1984: 25-9).

When two pastoral leases in the north of the region were resumed by the federal government in 1978, the NLC lodged a further claim. The Alligator Rivers Stage II Land Claim covered those former lease areas as well as that part of the first claim area that had not been granted. Ian was contracted again by the NLC to research this claim (Keen 1980), but it succeeded in winning only a small further area of land in the northeast. Ian himself later took issue with some of 
the positions adopted by the Aboriginal Land Commissioner that had led to such a poor outcome (Keen 1984). Nevertheless, many of the senior people who lived in or near Kakadu National Park at the time of its establishment in 1979 were recognised as traditional owners of their clan estates by one or both of these land claims. ${ }^{1}$

The policy revolution that occurred in Aboriginal affairs in the 1970s, and especially the advent of statutory land rights in the Northern Territory, marked a watershed in the history of engagement between a generation of Aboriginal men in the Alligator Rivers region and Australian society as represented by a succession of white interlocutors. This chapter proposes a way of understanding that watershed as a change in what those interlocutors were asking for, from skills to stories. It describes aspects of how the change occurred in the institutional and political context of the Alligator Rivers region. It then begins to address the question of how successfully those men met the changed expectations of the land rights era by considering the example of one of their number.

\section{Working Lives}

The generation of senior men who experienced the land rights process had substantial employment histories behind them by the mid-1970s. They had worked for a number of employers in a variety of jobs, mostly in the area between Darwin, Pine Creek, and Oenpelli mission. Much of this was the buffalo country that stretched east from Darwin across floodplains and savannah woodlands, a region that from the 1880 s to the 1950s was an economic backwater of buffaloshooting camps, poorly developed cattle stations, timber camps, garden leases and small mining shows. The fossicking economy (Levitus 1995: 69) that persisted there over those decades consisted of often-transient enterprises requiring little capital, but it provided opportunities for dry-season employment of Aborigines doing bush work in return for European commodities and, mainly in the later years, some money.

Around its edges were other, more stable options. To the northeast was Oenpelli mission, to the northwest the town of Darwin, and to the southwest the small mining and servicing centre of Pine Creek. Connecting the first two were luggers that worked their way along the coast and rivers, and between the latter two were a railway line, mines and other smaller settlements. During the war there were army compounds along the railway line. Then in the 1960s,

\footnotetext{
1 Ian's involvement in the Alligator Rivers region did not end there. He carried out other projects, including a site survey on a proposed extension of the Arnhem Highway, a report on traditional ownership of the Koongarra mineral lease, a report for the Resource Assessment Commission on the Kakadu Conservation Zone and, much later, another land claim.
} 
small abattoirs, buffalo domestication projects, tourist safari camps, crocodile shooters and barramundi fishermen developed new entrepreneurial niches in a region that now attracted serious policy attention from the Northern Territory administration, but still little from Canberra.

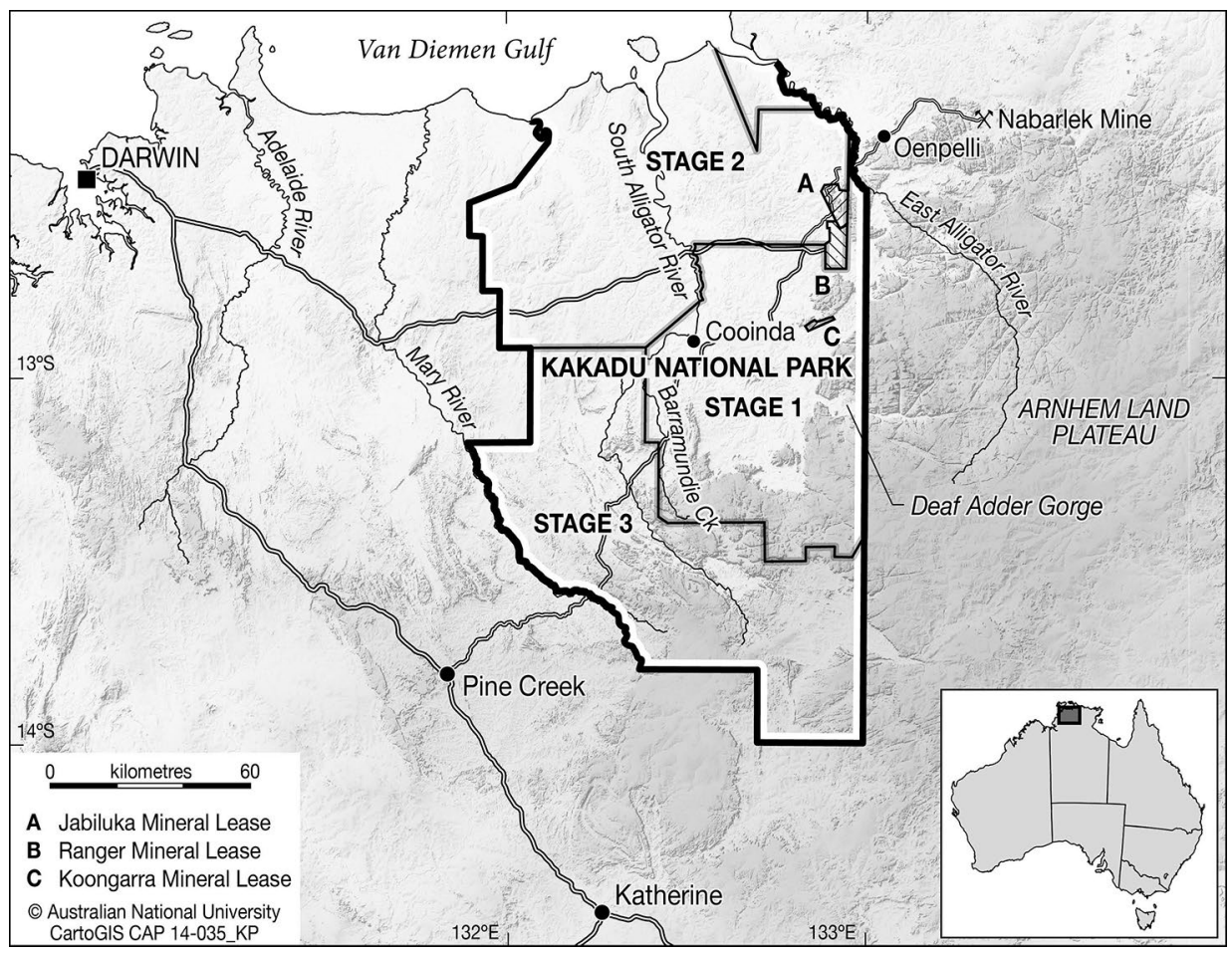

Figure 4.1 Kakadu National Park and surrounds.

Source: The Australian National University.

Aboriginal men from the Alligator Rivers region whose life histories I have researched worked widely across this region and sometimes well beyond. They often started young, around the camp, collecting wood and water, doing simple cooking and tending animals. Their various later jobs included buffalo shooter, crocodile shooter, stockman, horse breaker, pig catcher, builder, driver, fisherman, boat crewman, slaughterman, municipal worker, timber getter, safari guide, and labourer. They were mobile and versatile, they knew their own value as workers, and the skills and experiences they accumulated were often a source of pride and repute in their later years.

For most of their adult lives, it was in these capacities that they had engaged with white society. Bush entrepreneurs sought them out for their abilities at shooting buffalo from a galloping horse, skinning without damaging a hide, breaking in wild brumbies, droving over long distances, working a canoe quietly and 
quickly within harpooning range of a crocodile at night, or the hard hot work of providing a new station with an airstrip, abattoir and yards. The skills they offered were not only those of the introduced economy. Their native bush skills, especially a facility for navigation that their white employers sometimes found uncanny, added to their value as workers.

By the early 1970s, much of this employment had ended in the buffalo country. The buffalo hides industry ceased in 1956, the introduction of equal wages drastically reduced Aboriginal employment on stations in the late 1960s, saltwater crocodiles had been hunted out and were declared a protected species in the Territory in 1971, and many people had begun overusing alcohol. Nipper Kabirriki, whom I later discuss, was among those sitting unemployed at Pine Creek, watching a steadily growing stream of tourists passing through on their way to the bush attractions of the Alligator Rivers region in the eastern buffalo country.

\section{The New Regional Design and Aboriginal Power}

Then, the discovery between 1969 and 1973 of the major uranium deposits of Ranger, Nabarlek, Koongarra and Jabiluka raised for the Australian government the question of how this powerful industrial interest was to be brought into some form of accommodation with the assertive new political discourses of Aboriginal rights and environmental conservation. During the remainder of that decade, the Alligator Rivers region was a consistent focus of national controversy and passed through a phase of major political, institutional and infrastructural transformation (Lawrence 2000). The first land claim was granted, the Ranger mine was approved and constructed, a town was built nearby to house the workers, and the first stage of Kakadu National Park was declared.

Critically, this transformation was effected by the Commonwealth government (Lawrence 2000: 91-5). While previously the Commonwealth had allowed the Territory to decide land use, it now refused to transfer power over Aboriginal land rights or over major land use decisions in the Alligator Rivers region to the Territory administration under the self-government package then being negotiated (Heatley 1990: 70-3, 91-2, 130). The Commonwealth instead exercised recently acquired statutory powers to determine a new regional design. Three such exercises of power are relevant here. The Ranger Uranium Environmental Inquiry was instituted by the Whitlam government under the Commonwealth's Environment Protection (Impact of Proposals) Act of 1974, the land claims were heard pursuant to the 1976 Commonwealth land rights legislation, and the major ultimate land use, that of national park, was vested 
in a new Commonwealth agency, the Australian National Parks and Wildlife Service (ANPWS; Haynes 2009: 57-62), respectively declared and created under the National Parks and Wildlife Conservation Act of 1975.

In the formative years of the mid to late 1970s, these intersected. The Ranger Inquiry bestowed on the region's A boriginal population its first serious recognition as a central interest group and studied the likely impacts of development upon it (RUEI 1977: 225-33). The Land Rights Act transferred existing reserve lands in the region to Aboriginal ownership and empowered the inquiry to hear the first land claim (see above). The inquiry also recommended the creation of a major national park over a large part of the region, to be declared under the Commonwealth Act rather than the Territory Ordinance (ibid.: 334). It further recommended that Aboriginal participation in park planning and management should apply to the whole of the national park, including areas that were not legally Aboriginal land (ibid.: 205-6). All of this was implemented.

There had been a turnover in the incumbencies of power in the Alligator Rivers region, and the new Commonwealth incumbents professed a truth about Aborigines that was different to that of their Territorian predecessors. Acceptance of Aborigines' interests in land and their concomitant right to be consulted about its use instigated a change in their formal status from a passive, uninformed and disregarded population of onlookers to a central interest group whose participation in the affairs of the area had to be elicited. This new nationally promulgated legal and administrative regime had refigured Aborigines. People known through the years as seasonal bush workers, wards of the state and welfare recipients, could now be installed as traditional owners of land and custodians of sites, and met with as self-determining participants in consultation.

In the wake of these and other decisions relating to governance, development, land ownership and environmental management, the impact of this late 1970s multi-stranded policy process on Alligator Rivers Aborigines was the subject of much inquiry and debate (Australian Institute of Aboriginal Studies 1984; Tatz 1982; von Sturmer 1982). Much of that debate went to the question of whether the change in their legal standing had effected change in their political standing: what authority and control had passed into local Aboriginal hands. One common critical theme in these writings was that the transfer of land ownership to Aboriginal people was not accompanied by a power of determination over the new jurisdictional and institutional design being put in place over the region, or the developmental future anticipated for it.

The crucial decision in favour of mining the Ranger deposit was taken in disregard of Aboriginal opposition (RUEI 1977: 9). Accompanying this development, a complex structure of regulation and administration, which became in itself 
a social impact of mining, was imposed on the region (Gray 1980: 147-8; von Sturmer 1984b: 120-31). Land rights satisfied the formal preconditions for Aboriginal participation and influence, but their exercise could be smothered by a cluster of organisational mediators. Von Sturmer identified the incongruity within the Ranger Inquiry between land rights and the exercise of authority and responsibility with respect to the land. He noted the absence of direct evidence from local Aboriginal people, and the denial of a future determining voice to them, in favour of external specialists: the Northern Land Council, the director of the Australian National Parks and Wildlife Service and the Supervising Scientist (von Sturmer 1984a: 84-5, and see 53-6).

Nor did it appear, from the Ranger Inquiry's qualitative assessment of Aboriginal capacity, that it anticipated the emergence of any confident local Aboriginal determining voice. The inquiry saw a demoralised and beleaguered population (RUEI 1977: 46) for which it recommended a series of ameliorative measures that I have elsewhere summarised as a 'design for protection' (Levitus 2005: 30-1). Von Sturmer (1984a: 83) similarly remarked on the 'general air of malaise and decay and hopelessness which hovers over everything'. In the mid-1990s, the activist Jacqui Katona (personal communication), representing the Mirarr traditional owners in their opposition to development of the Jabiluka uranium deposit, remarked that land rights had not been worth a 'hill of beans' to the people of the Alligator Rivers region.

\section{Kakadu and Consultation}

But in a region suddenly crowded with interest groups and agencies of the state, Aboriginal influence did find two institutional homes to the west of the East Alligator River. One of these, the Gagudju Association, took on an importance in the 1980s that had not been anticipated by the region's planners (Levitus 2005). The other was Kakadu National Park. It is the latter that is important to my present theme. Even as capital and the state had their way in the Alligator Rivers region, policy and politics combined in Kakadu to create new space, politically and geographically, for Aboriginal people.

Following Ranger Inquiry endorsement, the principle of Aboriginal participation in management of the entire park had been accepted by the federal government and the ANPWS from the beginning (Viner 1977: 4; Wellings 1995: 242). However, the formal settings did not look promising. The terms of the lease from the traditional owners to the Commonwealth, and the first Plan of Management, were not strong on the point (Lawrence 2000: 99-101, 180-1; Tatz 1982: 153-6), there was no board of management on which Aboriginal numbers could dominate during the first decade of the park's existence (Haynes 2013: 
198), and one critic perceived a fatal ambiguity in the term 'management' itself, between high-level policy and planning, and everyday ground-level ranger work, that he thought the Parks Service was exploiting to exclude traditional owners from real control (Tatz 1982: 175-6).

But that same critic described the first ANPWS officers in Kakadu as 'excellent and admirable', 'moral and caring' (Tatz 1982: 155-6). Those first park managers tried to institute a style of relationship with the traditional owners that would give some substance to land rights. As one of these officers, Chris Haynes, later wrote, 'That was through the best dialogue we were able to imagine at the time' (Haynes 2009: 164). ANPWS began its work in the region with a principled commitment to consultation. The first three parks officers to arrive in KakaduHaynes, Dan Gillespie and Ian Morris - were recruited

on the strength of our demonstrated ability and experience to relate to the traditional owners, and so we were given a free hand to do what we knew best. Although aware that the formal [park lease] agreement had made almost no direct provision for the voice of traditional owners to be heard, it seemed inconceivable to any of us that important decisions on Aboriginal land could be made without consultation with its traditional owners. And so, with the approval of an alreadyoverworked Northern Land Council we initiated dialogue with traditional owners immediately. (Haynes 2009: 160; see also Gillespie 1984)

Here in this new institutional setting, those senior Aboriginal men with substantial working lives already behind them were invited to engage with a new set of white interlocutors who adhered to a new truth about Aborigines and wanted to hear their stories. Haynes and Gillespie shared the prior experience of witnessing John Hunter's methods of genuine engagement with the Aboriginal people of Maningrida during his tenure as superintendent (Gillespie 1982). Now in Kakadu, they shared the task of general liaison with the Aboriginal residents, spreading news and information, and raising the initial questions of park planning. Their consultation style was personal, informal and cumulative:

Consultation did not just entail one-on-one or group meetings about the agenda of the moment. It was surrounded by hours and days of casual discussion in all sorts of locations - and just simply exchanging information. Thus when there were issues for decision-making each side had some understanding of the other's positioning. Our personal associations grew while looking at items of interest: in the field, in cars, on house verandas, under caravan annexes, and in shops and pubs. Sometimes there was a lot of note-taking but often it was just the sharing of opinions and stories. (Haynes 2009: 161)

By this communicative process, some Aborigines were refigured as actors in the public affairs of the region. Von Sturmer (1984c: 156) observed that 'of all the essentially European organisations operating in the Region, ANPWS has the greatest sensitivity to and knowledge of Aboriginal issues and politics'. 
Park management was of course not the only originator of consultations, although combined with the various academic research projects pursued in the park by archaeologists, linguists and others under the aegis of ANPWS, it accounted for a large proportion. But there were also consultations with other agencies and individuals about traditional ownership issues, proposed mines, further land claims, management of royalty and lease payments, sacred site documentation, popular films and books, commercial developments and social programs. Not all these consultations were of the same quality as those of the early Kakadu years (von Sturmer 1981; Gundjehmi Aboriginal Corporation 1997).

\section{The New Terms of Engagement}

The politicking of the 1970s and the settlement of new jurisdictional and institutional arrangements by the end of that decade were only the beginning. Consultation was now the standard and it operated as a two-edged sword of both a right and a burden. In the lives of the senior generation of the time, I treat this as a change in the currency of their articulation with non-Aboriginal society. Having been asked for skills in their earlier lives, they were now being asked for stories. Later, by way of an individual example, I begin to address the question of how they responded to the potentialities thrown up by that change.

By stories I mean cultural accounts: genealogies, language, life histories, myths, sites, livelihood patterns, the identities and meanings of country and people's connections to it, and judgements as to what entitlements arose from those connections and what activities might be allowable on that land. They were being asked to articulate local Aboriginal cultural values, especially values of place, and to say how those values should properly be recognised in the new regimes of management and development. In a less directly instrumental way, they were also being asked to inform and enrich the new European appreciation of Kakadu with the stories of its own people, their lives, languages and places. One prominent man, Bill Neidjie, came to recognise this new time as one that placed whites themselves under an obligation.

This time White-European must come to Aborigine,

listen Aborigine and understand it.

Understand that culture, secret, what dreaming. (Neidjie 1989: 78)

But the Aboriginal people who claimed attachments to the region were often initially surprised that they should be consulted at all. That they should be asked by whites of some apparent official standing to consider the plans of whites of some apparent power (sometimes the same ones) and express judgement upon them was new in their experience, and confusing or embarrassing for some. When Keen and Chaloupka were contracted to research the first land claim 
in 1975 (above), they were initially asked to also ascertain the opinions of the claimants regarding the proposed uranium developments. While this task was not pursued systematically, Keen gained the impression from those people he did approach that they had no idea as to why they were being asked.

A few years later, by which time consultation had become more familiar, the invitation to participate in processes of decision and control could still be unsettling. Chris Haynes, one of the first generation of senior managers of Kakadu National Park, approached Mick Alderson, one of the central traditional owners of the park land, to contribute to the development of initial management strategies:

When I asked his view about an issue in the first months of our association he often giggled a bit, looked at the ground embarrassed, shrugged in an exaggerated and prolonged manner, and said, 'It's up to you'. After perhaps some silence, he might continue ... 'You've got the lease. The park has gone to you mob. You're supposed to know what to do.' (Haynes 2009: 162)

Such confusion and hesitation were the responses of people discovering that the terms of the intercultural had suddenly and unaccountably changed. The transition from skills to stories presupposed that different white interlocutors were now seeing Aborigines differently and expecting different things from them. As before, their interlocutory position was a manifestation of white authority. Whites sought Aboriginal engagement with and contributions to exercises of white design, even if, in the case of the search for stories, they were designs for cultural recognition. The framework of consultation was itself always a non-Aboriginal creation, an artefact of a progressively liberalising colonialism.

Participation in these designs exposed Aborigines to the normative regimes that governed them. Those regimes proposed and then inculcated models of personhood appropriate to effective participation. We find in Judith Butler an explanation of how this operated as an instance of Foucault's 'politics of truth':

The politics of truth pertains to those relations of power that circumscribe in advance what will and will not count as truth, which order the world in certain regular and regulatable ways, and which we come to accept as the given field of knowledge. We can understand the salience of this point when we begin to ask: What counts as a person? What counts as a coherent gender? What qualifies as a citizen? Whose world is legitimated as real? Subjectively, we ask: Who can I become in such a world where the meanings and limits of the subject are set out in advance for me? By what norms am I constrained as I begin to ask what I may become? (Butler 2002: 220-1) 
So we are concerned with the intelligible formation of the subject within a given historical scheme of things', a 'self-crafting, which always takes place in relation to an imposed set of norms' (Butler 2005: 17, 19). The work camps that senior men had grown up around and been recruited into required that they adopt the subjectivity of the bush worker. McGrath (1987: 167-9) discusses this process as one of identity formation on the part of Aboriginal stockmen in north Australian cattle station camps. Similarly, the expectations, requirements and commitments of working lives spent in the buffalo camps and other fossicking economy sites constituted a normative environment that conditioned the emergence of certain kinds of person who understood their own narratives in terms of their relationships to that environment (Butler 2005: 7-8).

What the transition from skills to stories showed was that the narratives crafted from those relationships were not comprehensive. They did not exhaust the potential for self-narration that could be found within those life histories. To different degrees for different members of the senior land claim generation, subsisting alongside the accumulated experiences of work were items or themes of learning of precolonial origin - though sometimes acquired in the course of employment-including information about Aboriginal land relationships (see Merlan 1998: 79-96). The surprise and discomfort of people experiencing their first moments of consultation is testimony to the long-standing irrelevance of this kind of knowledge for establishing an Aboriginal subjectivity that could be viable in relations with whites. The sources of this new relevance and new viability have already been indicated.

Predominant among them was the Land Rights Act and the new legal status of traditional owner that it instituted. Merlan (1998: 166ff) has discussed how traditional ownership is formulated in law and tested in court as an exercise in the structured and reified imitation of precolonial relationships to land. While she emphasises the changing but persistent gap between such formulations and social reality, the important point here is that that legal imitative exercise was sufficiently successful to resonate with Aboriginal claimants and provide them with a model around which they could marshal their memories and to which their current self-representations could aim to approximate. It referred to something that they knew, or felt they should know, something about. ${ }^{2}$

Following that was the takeover, or withholding, of Territorian political authority by the Commonwealth in the Alligator Rivers region, and the commitment that its politicians and agencies professed to an ideology of self-determination. Finally there were those frontline personalities - Keen, Chaloupka, Haynes, Gillespie and Morris have already been named-who were experienced in recognising

2 Povinelli (2002) offers extensive critical discussions of this point. 
Aborigines as something other than bush workers even before land rights were legislated and before any of them (except for Chaloupka) began working in the region. I mentioned earlier that the Commonwealth professed a different truth about Aborigines than had the Territory. These individuals tried to hold to that truth. That different truth, of Aborigines as participating landholders, constituted in Butler's terms a normative frame for the encounter between them.

In asking the ethical question 'How ought I to treat another?' I am immediately caught up in a realm of social normativity, since the other only appears to me, only functions as an other for me, if there is a frame within which I can see and apprehend the other in her separateness and exteriority. So, though I might think of the ethical relation as dyadic or, indeed, as presocial, I am caught up not only in the sphere of normativity but in the problematic of power when I pose the ethical question in its directness and simplicity: 'How ought I to treat you?' If the ' $\mathrm{I}$ ' and the 'you' must first come into being, and if a normative frame is necessary for this emergence and encounter, then norms work not only to direct my conduct but to condition the possible emergence of an encounter between myself and the other. (Butler 2005: 25)

We are dealing then with how people responded to a change in the normative frames created for their encounters with whites (cf. Batty 2005). The rest of this chapter is about how one man met the demand for skills in earlier times, and especially how he then managed the new interest in stories. It shows how someone who had felt confident of his value as a worker during an earlier era now fared when engaged by one of the land rights era's primary intended instruments of empowerment-consultation.

\section{Nipper Kabirriki}

Kabirriki was born in a cave in the western Arnhem Land plateau, and spent his early years living an Aboriginal bush life with minimal white contact. His country, Badmardi clan territory, is centred on Deaf Adder Gorge, which straddles the Kakadu/Arnhem Land boundary. As a boy before World War II, he saw the first buffalo come into his country. It was speared by his brother and they ate the meat. His memories of his family's annual round of travel well beyond the limits of that estate provided the substance of Chaloupka's remarkable early paper 'Badmardi Year of Seasons'. ${ }^{3}$ When talking of those areas, Kabirriki remembered place names in the order in which they would be

3 Later published as Chaloupka 1981. 
visited, as lines of travel, whether wet season rock shelters on the plateau, or billabongs and swamp pockets along a lowland creek: 'I have to go all around, every place. ${ }^{4}$

Kabirriki commented that in those old days people had moved around and camped all over, wherever they wanted. Since he had started working for whitefellers, he didn't walk around anymore. Whitefellers had quietened people down, he said. He took credit for being a reliable worker. He said he had had no bad bosses, because he had been a good man. Throughout his working life he didn't 'bad name' himself. If a white man told him to do something, he did it well. He worked on a number of cattle stations around Pine Creek and Adelaide River, and for several buffalo shooters between the Mary River and Deaf Adder Gorge. In the most distant venture from the Alligator Rivers that I recorded from that generation, he was part of a team that drove a mob of horses north from Alice Springs. He did building work on the Pine Creek pub, and worked for a butcher in Katherine, and at a gold mine near Barramundie Creek.

For Kabirriki, the transition to a regime of recognition for stories came early. The first policy response to the uranium discoveries was the Alligator Rivers Environmental Fact-Finding Study in 1972-73. It included an archaeological survey for which the researcher, Johan Kamminga, recruited him as an informant. They did two trips into Deaf Adder Gorge, within Kabirriki's own traditional estate, which he had not visited since the last years of the buffalo-shooting industry about 20 years before.

Kabirriki later spoke of the first of these trips as the means by which he, alone, had resumed contact with his country. He said that during his working years, no one had looked after his country. Then in the 1970s, people came looking for him and picked him up. His father and mother had been dead a long time, and when he went into Deaf Adder on that first trip, he went alone with the archaeologist and there was no one there. Shortly afterwards, he identified a location at a billabong outside of Deaf Adder for the establishment of an outstation, Kolondjorr, which he subsequently referred to as 'my station'. He then resumed intermittently living near and visiting his country.

The fact-finding study began Kabirriki's elevation to public status as a knowledgeable elder, perhaps the most knowledgeable, of the Kakadu area. It was a status that he enjoyed and of which he boasted. The land claims and the early phase of park management consummated the process, but it was also husbanded and sustained by another research relationship. Soon after that first field trip, he began assisting the exploratory rock art specialist George Chaloupka, and continued doing so until Kabirriki's death in 1987. For over a decade in 
the 1970s and 1980s, the partnership between Kabirriki and Chaloupka was probably the most important single conduit for lodging the cultural significance of the Kakadu landscape in the archive and representing it in the public domain (Chaloupka 1993; Flood 1997: ii).

One of the earliest and most important projects by that partnership, in company with Ian Keen and three other informants, was the bush trip to document clan territories and sites over most of what later became the first stage of Kakadu National Park. This research, discussed earlier, was written up into two reports for what became the first land claim under the new Land Rights Act. Kabirriki went on to act as an important source of information, again for Ian Keen, in the Alligator Rivers Stage II Land Claim. This claim included 11 patrilineal clan territories: nine in the north of the park and two in the south (Keen 1980). Kabirriki participated in field trips to nine out of the 11 estates, easily more than any other of Keen's informants, and was the only one able to provide information about clan territories in both areas of the park. He continued to work with Chaloupka on major site documentation exercises, and in 1981 he accompanied Rhys Jones' archaeological research team when it excavated and surveyed several Kakadu sites (Jones 1985). In all of these research exercises, and especially his wide-ranging explorations of stone country areas with Chaloupka, Kabirriki was encouraged in what was mostly a single-handed project of giving names and attributing significance to country, places and paintings.

Kabirriki was well equipped to flourish in this new era. His value to researchers lay in his ability to confidently recite from what appeared to be a substantial corpus of knowledge retained from his early years of bush living. A botanist working in the area considered him clearly the most knowledgeable person for trees and landscape, and remarked that even people of the East Alligator area, well away from Kabirriki's country, deferred to his expertise (Russell-Smith personal communication). Jones (1985: 20) called him 'a man possessing profound knowledge about the traditional affairs of his culture'. These assessments reflected Kabirriki's own: 'I know all the story and law from when I was kid. My father and grandfather tell me. I remember any story.'

He was forthcoming with what he knew. On field trips he gave information abundantly. Each stop might elicit place names and their geographical order and context, the people that camped or events that took place there, methods of hunting and cooking bush foods, or the travels of dreamings and the ceremonies that they brought to different places and groups. He presented a geography of traditional ownership for areas of the park, indexing each set of place names that came to mind against patrimoiety, clan, language group or individuals. Where an area had no surviving patrilineally descended traditional owners, he might designate a proper successor: 'Paddy gotta take that country.' 
Kabirriki was also one of four senior men recruited to show aspects of Aboriginal culture for Breeden and Wright's (1989: 150-75) popular book on Kakadu. The authors described him as 'the repository of the Dreamtime stories and their application to everyday life' (1989: 150). Their front dustjacket photograph (Figure 4.2) shows Kabirriki as custodian of country.
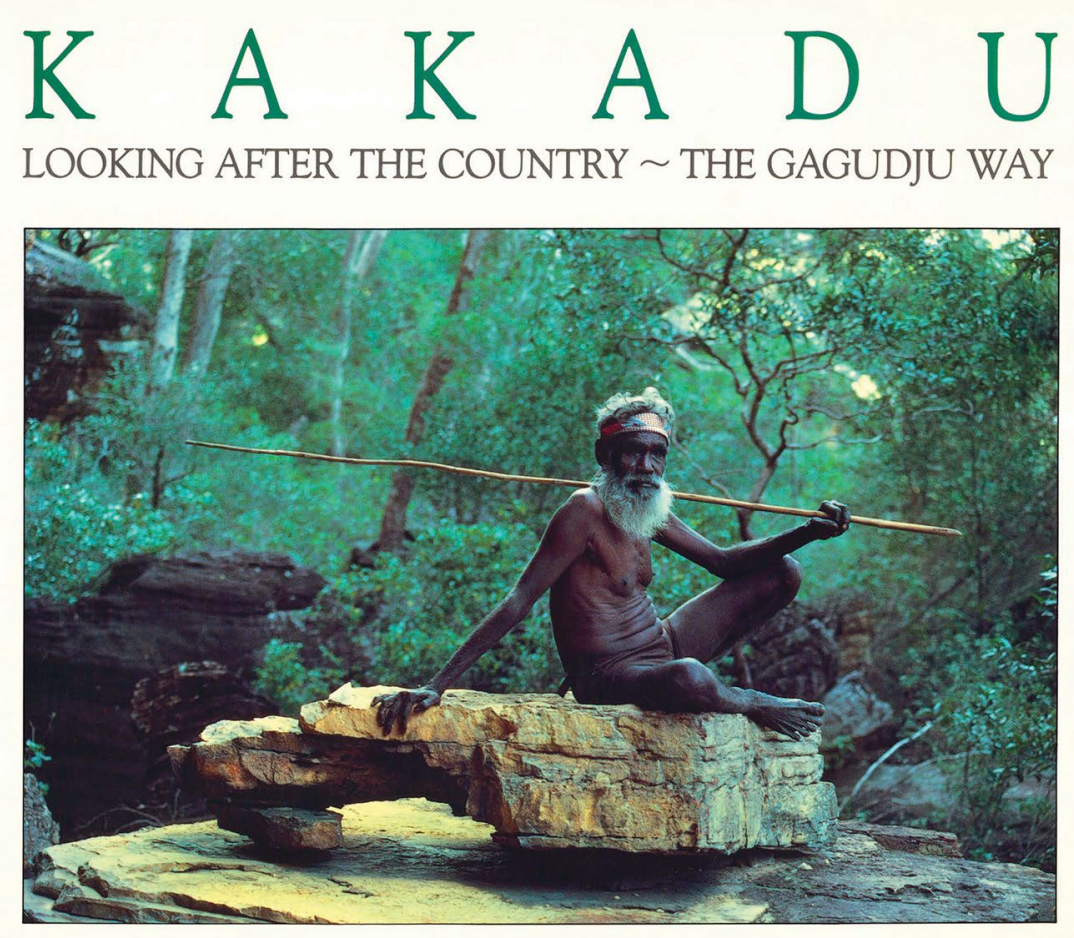

Stanley Breeden and Belinda Wright

Figure 4.2 Kabirriki on the cover of Kakadu.

Source: Belinda Wright/National Geographic Creative.

Despite the artifice of the photograph, Kabirriki's straight and confident gaze at the camera bespeaks his comfort with that persona. Not only would the photo have appealed to him as a way of publicly disseminating his custodianship, but it also implied real capability. The picture claimed for Kabirriki a subsisting native bush competence that he could have resumed practising had it been necessary to do so. Two other photos (Figures 4.3 and 4.4) featured in other popular books. Both taken by Chaloupka, they place Kabirriki in even closer association with ancient Aboriginal culture. 


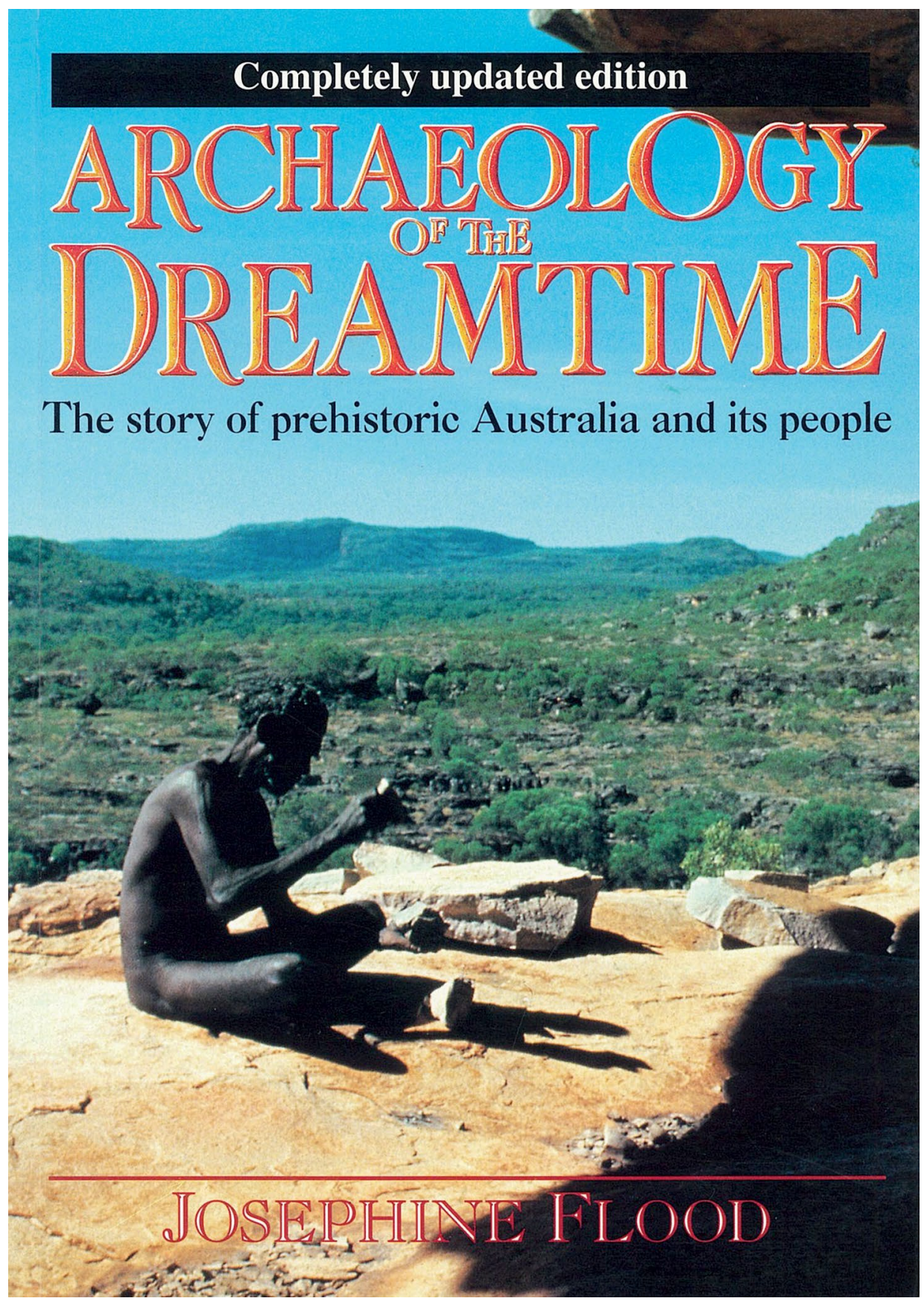

Figure 4.3 Kabirriki on the cover of Archaeology of the Dreamtime.

Source: George Chaloupka. 


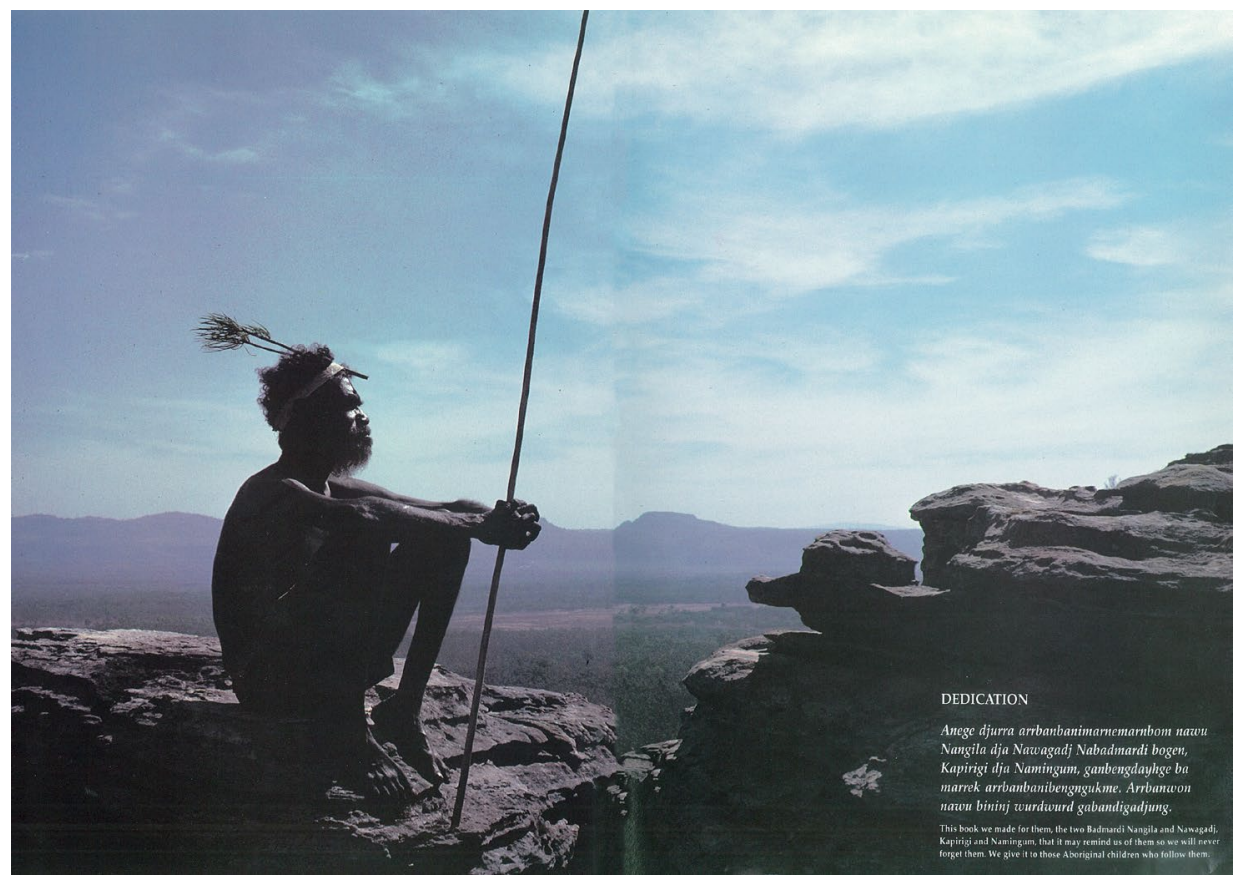

Figure 4.4 Dedication page from George Chaloupka, Journey in Time. Source: George Chaloupka.

Having been reinstated into a relationship with these stone country places by both a mimetic policy process and traditionalist research projects, Kabirriki nurtured and displayed that relationship through both embodiment, as shown in the photos, and story. He told once how he had been mad for two nights during which two female mimi, or rock country spirits, had picked him up from his station at Kolondjorr and taken him into Deaf Adder Gorge. There the mimi showed him two bush medicines that he could boil up and drink to cure his tuberculosis, in place of the ineffective 'white doctor medicine'. After being taught about his own wild medicine by the mimi he had come good.

That performative impulse extended to the tourists who arrived in Kakadu in rapidly growing numbers in the years after the land claims. Kabirriki would spontaneously introduce himself into conversation with groups seated at the Cooinda pub. He also encouraged the dissemination of stories about places as a way of discharging the responsibilities of custodianship (Gabirrigi 1984). He regarded this as a necessary means by which park rangers and traditional owners could take proper care of Kakadu and protect tourists from danger.

Kabirriki had a strongly individualistic sense of the importance of his record of fieldwork. The first trip to Deaf Adder for the fact-finding study (above) became for Kabirriki the instrument for claiming a singular pioneering role with 
respect to his country, despite the presence on that trip of two other Aboriginal men. He thought of his contribution to the land claims as an equally singular achievement, eclipsing the contributions of others. In recalling the seminal research trip in 1975 for the first claim, he said that 'Chaloupka and Ian Keen and me went all over', listing a series of locales - Anbangbang, Nanguluwurr, Burrunguy, Djelandjal, Djanbaldjakakodj-encompassed in their accelerated journeyings through the bush. He omitted to mention the three other senior men who participated in that trip, including his half-brother. Another time, at a casual night-time gathering in one of the Kakadu camps, Kabirriki observed how he and one of the other men present were united by a mutual life-history involvement in each other's countries, so he had come from Deaf Adder to help this man's group win their land.

There was little exaggeration in this. Keen (personal communication) himself recalled the documentation for the first land claim as being heavily reliant on Kabirriki, and I indicated above his pre-eminence in the second claim. The energy that Kabirriki had devoted to these efforts, and the kudos that he claimed from them, demonstrated his sense of what was to be gained from this new generation of white interlocutors and their projects of cultural recognition. He understood that in the era of land rights, knowledge and stories were the raw material of personal standing and authority, a potentiality that could be realised when one had a white person to 'book it down', something that he regularly instructed us to do: 'George Chaloupka, Ian Keen, Chris Haynes, Rhys Jones, Ian Morris ... they got all my word, all my story. They got it in their book. No one can cheat me now. I gotta win'.

He also grasped that behind these individual researchers was a higher institutional authority that was similarly receptive and could legitimate his claims. One such claim was to have succeeded to authority over a nearby clan estate with no remaining owners, so that he was now the boss all the way from his country to that one. He announced that he would soon be going to Canberra with Jones and Chaloupka, 'and then I'll be big boss for whole lot'.

Kabirriki's standing was widely acknowledged locally, especially among younger people. One man referred me to him with the recommendation that 'he was first man been write 'em down all the place and dreaming for land claim'. Kabirriki reciprocated with a critical eye over the claims and pretensions of his fellows. He forthrightly advised me that I was misguided in working with one very old local man who Kabirriki thought 'don't know nothing', and he gave the same evaluation of two other men who in the 1970s had purported to act as informants for his own country of Deaf Adder Gorge before Kabirriki himself had returned from Pine Creek: 'Which one proper right man? Well I'm the right man really for this country.' 
He had no patience with those other Badmardi people who had failed to learn about their country, had ignored his attempts to teach, and 'only savvy beer'. His view was that if a government man or lawyer were to come, it was the responsibility of those people to prove their claim with their own knowledge. If they called for his assistance with place names, he would say he didn't know. If they didn't know and he did know, well then they should get out and he would make it his own country. He was already looking after it. But also, in the early years of widespread royalty distributions from the Ranger mine (Levitus 1991), he adopted the cause of a man whose attachments to another area Kabirriki believed entitled him to money, and declared his intention to send a paper to Canberra to right the situation.

While a personality such as Kabirriki's would have sought and achieved a measure of independent space and recognition in any context, he became a free operator by reason of a paucity of constraints upon him. Historical depletion and dislocation of the Aboriginal population of the Alligator Rivers region, and a long period in which traditional knowledge counted for little, meant that among the people who repopulated the park area in the 1970s and 1980s were only a limited number who could offer the stories needed by white interlocutors. In that context Kabirriki was a standout performer, but one whose prominence itself became problematic because his information often stood alone.

There was no rich and active traditionalist Aboriginal discourse by reference to which Kabirriki's statements could be verified; no well-populated network of similarly knowledgeable and motivated men to whom he might in the ordinary run of things be made accountable for his claims. Certainly there were some other, less assertive senior people who knew some areas well, and one could hear occasional grumblings accusing Kabirriki of taking liberties in his declarations about this or that topic, but there was no challenge and no arbitration. His knowledge came from his own memory and extrapolations, and his deployment of it was relatively unfettered by anything other than his own judgements. For those recording his information, his singular status meant there was no way to know how much of what he gave was genuine inherited knowledge. But his confidence was seductive and there was neither reason nor grounds on which to challenge what he said.

Some problems, however, became evident in time, and some of what he said was revised. In at least one instance this was of his own volition. During an early park management planning exercise, Kabirriki realised that he had previously put a place name on an incorrect location and so relocated it, blaming his mistake on Chaloupka for having made him go too fast (Haynes, personal communication). At a grander scale, the map of clan territories published in the Ranger Inquiry Second Report (RUEI 1977: 278) and widely reproduced thereafter had to be significantly revised, partly with the assistance of Kabirriki, in the context 
of later projects aimed at verifying traditional ownership of parts of the same region. Such examples leave the impression that during the first wave of consultation and documentation campaigns in the Alligator Rivers region in the 1970s, often carried out under time constraints, insistent researcher inquiries elicited from Kabirriki an overconfident response that later had to be rethought with the benefit of more careful recollection or deduction.

The public management domain, with its concern for rationale, consistency and precedent, also acted at certain moments to bring Kabirriki's views to account and limit his opportunistic deployment of stories. The area of Kakadu in the vicinity of his clan country, depleted of traditional owners, provided him with opportunity. Despite his being of opposite patrimoiety to that land, Kabirriki said he would look after the whole lot, because he knew all the places, and all those people were dead. This claim involved transgressing a categorical distinction that Kabirriki himself often invoked. But when a publicly authorised decision was needed as to who had succeeded to ownership of the Koongarra mineral lease, Kabirriki sat in conference with a few other senior men to arrive at a new determination of traditional ownership in the context of Keen's anthropological consultancy. Although there is no way of knowing who said what, it appears from the outcome that he did not persist with his private claim.

On another occasion, he agreed to assist a family that he had worked for in the buffalo camps and who were now trying to claim traditional rights in parts of Kakadu. When they visited Chris Haynes, the senior parks officer in Darwin, to press their case, he realised that Kabirriki was putting propositions concerning rights over an area of land that were different to what he had previously said. Haynes told Kabirriki that changing his story in that way would destroy his credibility as an informant. So where public land management issues arose, his excesses could be contained when an established ethnographic charter, often based to a great extent on his own previous testimony, was brought to bear by administrative action.

One other matter of succession was more personal. It was not entirely clear whether there were any young Badmardi. A few were proposed, including a woman for whom Kabirriki claimed paternity, but they stayed away. Some other younger people from other clans who he declared himself willing to teach were either not sufficiently interested or did not persevere. Ultimately Kabirriki and the other Badmardi died. Succession to a clan estate made important by its escarpment surrounds and Kabirriki's standing has only recently been settled amongst other interested family groups in Kakadu. 


\section{Conclusion}

This chapter is about how land rights changed the terms of engagement between Aboriginal and non-Aboriginal people in the Alligator Rivers region, and how one Aboriginal man responded to that change. I offer his case study as an indicator of individual particularity. With more space, other personal accounts could be given to widely different effects. Land rights were a watershed that altered the grounds of interaction and the criteria for success in the dealings that the men of Kabirriki's generation had with whites. Men who had gained access to desirable goods and found their place in the world through skilled physical labour, were now being asked to give an entirely different account of themselves.

That was not always easily or successfully done. Where once the principal question that the European world had put to such men was 'What work can you do for us?', that question had suddenly changed to 'What stories can you tell us?' Such a drastic change in the expectations they were called upon to meet required that they draw in a different way upon personal resources of memory and cross-cultural competence and confidence. It asked and allowed them to develop and project aspects of their personae, or their resources for selfnarration, previously of no interest or value to their white interlocutors.

The legal status of traditional ownership thereby brought people into a revised awareness of their place and value in the world of the Alligator Rivers region because it relocated them within a new normative frame. Self-determination and land rights, as realised in Kakadu National Park in the 1980s, created new interaction frames in which Aboriginal people, upon whom the new status of traditional owner had been bestowed, were invited or required to participate. These new frames allowed them to take advantage, as well as they could, of the new officially legitimated truth about Aborigines, and to practise and test a new mode of subjectivity for its viability in relations with a new generation of white interlocutors.

Policy impacts categorically, but people live individually. When the land rights era introduced a consultation practice that took stories as its currency of recognition and prestige, Nipper Kabirriki discovered a new field of play open to him on which he could draw upon, reconstruct and elaborate the bush knowledge of his earlier life to easily accumulate status and prestige. After the land rights transition he began taking advantage of an absence of constraints and accountability which, for a personality such as his, were conditions of freedom. He was able to fully exploit the irony of a free-ranging individualist being anointed as a traditional authority. But the encounter between the imagined good of the consultative ethos, and individual Aboriginal subjectivities, had 
varied and unpredictable consequences. Other biographies would show that not all of Kabirriki's colleagues were able to find such advantage in the changed intercultural terms of engagement that were in play in the region.

\section{Acknowledgements}

My thanks go to Dan Gillespie, Chris Haynes, Lisa Palmer, Peter Toner and the anonymous readers for their comments on the draft. Thanks also to Pina Chaloupka for permission to use the two George Chaloupka photos, Karina Pelling of The Australian National University who prepared the map, and the Australian Institute of Aboriginal and Torres Strait Islander Studies for assistance with the Breeden and Wright photo.

\section{References}

Australian Institute of Aboriginal Studies. 1984. Aborigines and Uranium. Consolidated report to the Minister for Aboriginal Affairs on the social impact of uranium mining on the Aborigines of the Northern Territory. Canberra: Australian Government Publishing Service.

Batty, P. 2005. Private politics, public strategies: White advisers and their Aboriginal subjects [Special issue: Figuring the Intercultural in Aboriginal Australia, ed. M. Hinkson and B. Smith]. Oceania 75: 209-21.

Berndt, R.M. and C.H. Berndt. 1970. Man, Land and Myth in North Australia: The Gunwinggu People. Sydney: Ure Smith.

Breeden, S. and B. Wright. 1989. Kakadu: Looking After the Country - the Gagudju Way. Brookvale: Simon and Schuster.

Butler, J. 2002. What is critique? An essay on Foucault's virtue. In D. Ingram (ed.), The Political, pp. 212-26. Malden: Blackwell.

Butler, J. 2005. Giving An Account of Oneself. New York: Fordham University Press.

Chaloupka, G. 1975. Report on Aboriginal traditional land-ownership of the Alligator Rivers region: Part 2: The land-owning groups (clans) and their traditional territories. Darwin: Northern Land Council. 
Chaloupka, G. 1981. Appendix 1: The traditional movement of a band of Aboriginals in Kakadu. In T. Stokes (ed.), Kakadu National Park: Education Resources, pp. 162-71. Canberra and Darwin: Australian National Parks and Wildlife Service.

Chaloupka, G. 1993. Journey in Time. Chatswood: Reed.

Flood, J. 1997. Rock Art of the Dreamtime: Images of Ancient Australia. Sydney: Angus and Robertson.

Gabirrigi, N. 1984. Back to my country. In H. Sullivan (ed.), Visitors to Aboriginal Sites: Access, Control and Management, p. 59. Canberra: Australian National Parks and Wildlife Service.

Gillespie, D. 1982. John Hunter and Maningrida - a chorus of alarm bells. In P. Loveday (ed.), Service Delivery to Outstations, pp. 1-7. Darwin: North Australia Research Unit.

Gillespie, D.A. 1984. Ubirr - a case study in compromise. In H. Sullivan (ed.), Visitors to Aboriginal Sites: Access, Control and Management, pp. 19-28. Canberra: Australian National Parks and Wildlife Service.

Gray, W.J. 1980. The Ranger and Nabarlek mining agreements. In S. Harris (ed.), Social and Environmental Choice: the Impact of Uranium Mining in the Northern Territory, pp. 136-53. Canberra: The Australian National University, Centre for Resource and Environmental Studies.

Gundjehmi Aboriginal Corporation. 1997. 'We are not talking about mining': the history of duress and the Jabiluka Project. Accessed online 19 January 2014. www.mirarr.net/resources.

Haynes, C.D. 2009. Defined by Contradiction: The Social Construction of Joint Management in Kakadu National Park. PhD Thesis, Charles Darwin University, Darwin.

Haynes, C.D. 2013. Seeking control: disentangling the difficult sociality of Kakadu National Park's joint management. Journal of Sociology 49(2-3): 194-209.

Heatley, A. 1990. Almost Australians: The Politics of Northern Territory SelfGovernment. Darwin: North Australia Research Unit, The Australian National University.

Jones, R. (ed.) 1985. Archaeological Research in Kakadu National Park. Canberra: Australian National Parks and Wildlife Service and The Australian National University. 
Keen I. 1975. Report on Aboriginal traditional land-ownership of the Alligator Rivers region. Part 1: The land-owning groups (clans) and their membership. Darwin: Northern Land Council.

Keen, I. 1980. The Alligator Rivers Stage II Land Claim. Darwin: Northern Land Council.

Keen, I. 1984. A question of interpretation: the definition of 'traditional Aboriginal owners' in the Aboriginal Land Rights (N.T.) Act. In L.R. Hiatt (ed.), Aboriginal Landowners: Contemporary Issues in the Determination of Traditional Aboriginal Land Ownership, Oceania Monograph 27, pp. 24-45. Sydney: University of Sydney.

Lawrence, D. 2000. Kakadu: The Making of a National Park. Carlton South: Melbourne University Press.

Levitus, R. 1991. The boundaries of Gagudju Association membership: anthropology, law and public policy. In J. Connell and R. Howitt (eds), Mining and Indigenous Peoples in Australasia, pp. 153-68. Sydney: Sydney University Press.

Levitus, R. 1995. Social history since colonisation. In T. Press, D. Lea, A. Webb and A. Graham (eds), Kakadu: Natural and Cultural Heritage and Management, pp. 64-93. Darwin: Australian Nature Conservation Agency and North Australia Research Unit, The Australian National University.

Levitus, R. 2005. Land rights and local economies: the Gagudju Association and the mirage of collective self-determination. In D. Austin-Broos and G. Macdonald (eds), Culture, Economy and Governance in Aboriginal Australia: Proceedings of a Workshop of the Academy of the Social Sciences in Australia, pp. 29-39. Sydney: Sydney University Press.

McGrath, A. 1987. 'Born in the Cattle': Aborigines in Cattle Country. Sydney: Allen and Unwin.

Merlan, F. 1998. Caging the Rainbow: Places, Politics, and Aborigines in a North Australian Town. Honolulu: University of Hawai'i Press.

Neidjie, B. 1989. Story about Feeling (K. Taylor ed.). Broome: Magabala Books.

Peterson, N., I. Keen and B. Sansom. 1977. Succession to land: primary and secondary rights to Aboriginal estates. In Official Hansard Report of the Joint Select Committee on Aboriginal Land Rights in the Northern Territory. Canberra: Australian Government Printer, 19 April: 1002-14.

Povinelli, E. 2002. The Cunning of Recognition: Indigenous Alterities and the Making of Australian Multiculturalism. Durham: Duke University Press. 
Ranger Uranium Environmental Inquiry (RUEI). 1977. Second Report. Canberra: Australian Government Publishing Service.

Saddler, H. 1980. Implications of the battle for the Alligator Rivers: land use planning and environmental protection. In R. Jones (ed.), Northern Australia: Options and Implications, pp. 187-200. Canberra: Research School of Pacific Studies, The Australian National University.

Tatz, C. 1982. Aborigines and Uranium and Other Essays. Richmond: Heinemann Educational Australia.

Ucko, P. 1976. Review of A.I.A.S. activities 1975. Australian Institute of Aboriginal Studies Newsletter N.S. 5: 6-20.

Viner, I. 1977. Uranium-Australia's decision. Statement by the Hon. Ian Viner, Minister for Aboriginal Affairs and Minister Assisting the Treasurer. In Uranium - Australia's Decision, pp. 1-7. Canberra: Australian Government Publishing Service.

von Sturmer, J. 1981. Talking with Aborigines. Australian Institute of Aboriginal Studies Newsletter N.S. 15: 13-30.

von Sturmer, J. 1982. Aborigines in the uranium industry: toward selfmanagement in the Alligator River region? In R.M. Berndt (ed.), Aboriginal Sites, Rights and Resource Development, pp. 69-116. Perth: University of Western Australia Press.

von Sturmer, J. 1984a. A critique of the Fox Report. In Australian Institute of Aboriginal Studies, Aborigines and Uranium, pp. 20-103. Canberra: Australian Government Publishing Service.

von Sturmer, J. 1984b. The social impact of mining: 1. The complexity of law and administration. In Australian Institute of Aboriginal Studies, Aborigines and Uranium, pp. 119-32. Canberra: Australian Government Publishing Service.

von Sturmer, J. 1984c. The social impact of mining: 2. Economic consequences: II Residence, resources, and inequities. In Australian Institute of Aboriginal Studies, Aborigines and Uranium, pp. 133-77. Canberra: Australian Government Publishing Service.

Wellings, P. 1995. Management considerations. In T. Press, D. Lea, A. Webb and A. Graham (eds), Kakadu: Natural and Cultural Heritage and Management, pp. 238-70. Darwin: Australian Nature Conservation Agency and North Australia Research Unit, The Australian National University. 
This text is taken from Strings of Connectedness: Essays in Honour of Ian Keen, edited by Peter Toner, published 2015 by ANU Press, The Australian National University, Canberra, Australia. 